\title{
The Association Between Dental Anxiety and Oral Health Related Quality of Life Among Individuals with Mild Intellectual Disability
}

\section{Hafif Seviyede Zihinsel Engeli Bulunan Bireylerde Dental Anksiyete ve Ağız Diş Sağıı̆ı̆na Bağlı Yaşam Kalitesi Arasındaki llişki}

\author{
(1) Sultan Keleş ${ }^{1}$, (1) Filiz Abacıgil2 ${ }^{2}$, (1) Filiz Adana ${ }^{3}$, (1) Duygu Yeşilfidan ${ }^{3}$, (1) Pınar Okyay ${ }^{2}$ \\ ${ }^{1}$ Adnan Menderes University Faculty of Dentistry, Department of Pediatric Dentistry, Aydın, Turkey \\ ${ }^{2}$ Adnan Menderes University Faculty of Medicine, Department of Public Health, Aydın, Turkey \\ ${ }^{3}$ Adnan Menderes University Faculty of Health Sciences, Department of Public Health Nursery, Aydın, Turkey
}

Keywords

Dental caries, quality of life, malocclusion, dental anxiety

Anahtar Kelimeler

Diş çürüğü, yaşam kalitesi, maloklüzyon, dental anksiyete

Received/Geliş Tarihi : :09.09.2016

Accepted/Kabul Tarihi : 16.11.2016

doi:10.4274/meandros.3000

Address for Correspondence/Yazışma Adresi:

Sultan Keleş DDS, PhD.

Adnan Menderes University Faculty of

Dentistry, Department of Pediatric Dentistry,

Aydın, Turkey

Phone : +90 2562133939

E-mail :dtsultank@gmail.com

ORCID ID: orcid.org/0000-0001-7978-8715

(C) Meandros Medical and Dental Journal, Published by Galenos Publishing House.

This is article distributed under the terms of the

Creative Commons Attribution NonCommercial 4.0

International Licence (CC BY-NC 4.0).

\begin{abstract}
Objective: The aim of this study is to determine the oral health related quality of life and the effect of dental anxiety on the oral health related quality of life in young, mildly intellectually disabled individuals who are attending a special school.

Materials and Methods: Eighty six mildly intellectually disabled students participated this cross-sectional study. Oral health-related quality of life-United Kingdom Scale and Oral Health Impact Profile-14 were used to evaluate the effects of oral health of the individuals on their quality of life. Modified Dental Anxiety Scale was used to determine the dental anxiety levels of the individuals. Data were analyzed statistically.

Results: The mean age of the participants was $17.12 \pm 1.40$ years and the mean decayed, missing, and filled teeth (DMFT) score of the students was $3.10 \pm 2.76$. According to the Modified Dental Anxiety Scale, 28.0\% of the students had dental anxiety. A significant inverse relationship was detected between dental anxiety levels and oral health-related quality of life ( $r=-0.239 ; p=0.028)$.

Conclusion: Nearly $30 \%$ of individuals with mild intellectual disabilities were determined to have dental anxiety. Considering that the oral health-related quality of life decreases with increasing dental anxiety, it may be beneficial for dentists to administer premedication before treatment to decrease the anxiety levels of these patients.
\end{abstract}

Öz

Amaç: Bu çalışmanın amacı hafif seviyede zihinsel engeli olan ve bir engelli okuluna devam eden genç bireylerde ağız diş sağlığına bağlı yaşam kalitesini ve dental anksiyetenin ağız diş sağlığına bağlı yaşam kalitesi üzerine olan etkisini araştırmaktır. Gereç ve Yöntemler: Bu kesitsel çalışmaya hafif seviyede zihinsel engeli olan 86 öğrenci katıldı. Ağız diş sağlığına bağlı yaşam kalitesinin belirlenmesi için ağız diş sağlığına bağlı yaşam kalitesi-Birleşik Krallık Ölçeği ve Ağız Sağlığına Bağlı Etki Profili-14 ölçekleri kullanıldı. Dental anksiyetenin belirlenmesinde Modifiye Dental Anksiyete Skalası kullanıldı. Veriler istatistiksel olarak analiz edildi.

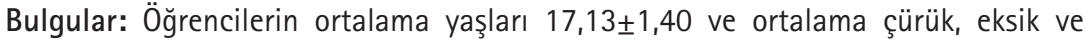
dolgulu diş sayıları (DMFT) 3,10 $\pm 2,76$ olarak hesaplandı. Modifiye Dental Anksiyete 
Skalası'na göre öğrencilerin \%28'inde dental anksiyete saptandı. Dental anksiyete ile ağız dişs sağlığına bağı yaşam kalitesi arasında negatif yönde anlamlı bir ilişki saptandı $(r=-0,239 ; p=0,028)$.

Sonuç: Hafif seviyede zihinsel engelli öğrencilerin yaklaşık \%30'unda dental anksiyete saptandı. Dental anksiyetenin artmasının ağız diş sağlığına bağlı yaşam kalitesini düşürdüğü düşünüldüğünde diş hekimlerinin, bu hastaların anksiyete seviyelerini azaltmak için tedavi öncesi premedikasyon uygulamaları faydalı olabilir.

\section{Introduction}

DDental caries is the most prevalent disease among intellectually disabled individuals both worldwide and in our country (1). Inadequate recall systems, practical difficulties during treatment sessions, socio-economic status, underestimation of treatment need or pain, communication problems, and lack of cooperation are the reasons that make dental treatment the greatest unattended health need of the intellectually disabled individuals(2,3). Poor oral health, including caries, periodontal problems, malocclusions, and dental trauma, has negative impacts on nutrition, digestion, the ability to chew, facial shape, and speech $(4,5)$. Therefore, these oral conditions have outcomes regarding both physical well-being and quality of life. There are many measures used to evaluate oral health-related quality of life (OHRQoL). The Oral Health Related Quality Of Life-United Kingdom Scale (OHRQoL-UK), developed by McGrath and Bedi (6), examines both the positive and the negative effects of oral and dental health on the quality of life in four different domains (psychological status, physical status, social status, symptoms). The Oral Health Impact Profile-14 (OHIP-14) measures the impact of oral diseases in the seven domains of Locker's model. The disability domain of Locker's conceptual model is further divided into physical, psychological, and social disability domains (7). OHRQoL leads clinicians to notice how people feel about their oral health or disease related to daily functioning, well-being, and social interactions (8). This subjective evaluation from the patients' perspective is critical to determine the clinical interventions for improving patients' OHRQoL.

Dental anxiety may be defined as a complex phenomenon that is influenced by fear of pain, personality characteristics, traumatic dental experiences in childhood, and dentally anxious family members or peers. Dental anxiety may interrupt the treatment of intellectually disabled individuals as well as healthy individuals, decreasing OHRQoL (9). Modified Dental Anxiety Scale (MDAS) is frequently used to measure dental anxiety (9). Although there are many studies that evaluate the oral health conditions of mildly intellectually disabled individuals in the literature $(1,10,11)$, there are no studies on the effects of malocclusion and dental trauma on OHRQoL or the relationship between dental anxiety and OHRQoL. Since dental anxiety negatively affects the demand for treatment and the treatment process, OHRQoL is found to be negatively affected as well. For this reason, studies that evaluate the relationship between dental anxiety and OHRQoL in mildly intellectually disabled individuals are needed. The present study is important in terms of evaluating dental anxiety levels in a group of individuals who are able to meet their own daily needs but neglect oral healthcare. The results will provide guidance in making treatment plans specifically for this group. Primarily, the aim of this study is to determine the oral health conditions and oral health attidues of the students studying in a school for the disabled and their relationship with OHRQoL. Secondly, it is to evaluate the relationship of the dental anxieties of the individuals in the study group with their OHRQoL.

\section{Materials and Methods}

The approval for this cross-sectional study was obtained from the Ethics Committee for NonInterventional Studies, Adnan Menderes University, Faculty of Medicine (2016/765). The written informed consent was obtained from the students and their parents or caregivers. The population of the study comprises the students of a school for mildly intellectually disabled individuals, located in the city center of Aydın. Samples were not selected; all students between the ages of 15 and $22(n=86)$ were included in the study. For data collection, an assessment set comprising one questionnaire form structured to encompass socio-demographic properties, one clinical examination form, and three scales were used. The questionnaire forms were created to record the socio-demographic data and examination results of the participants. The oral health status of individuals 
(DMFT value, history of dental trauma, malocclusions, periodontal condition) and the socio-demographic data (age, gender, the frequency of visits to the dentist, teeth brushing habits, parents' educational status, parents' working status, family's income status, family's health insurance status) were recorded. DAS, defined by Corah in 1969 in order to determine the dental anxiety level, comprises 4 questions; however, there is no means of assessment of anxiety to local anesthesia injections. Therefore, a question to assess the respondent's anxiety to oral injections was added to the scale, and the MDAS was attained. The scale comprises 5 questions, and the score results of the scale vary between 5 and 25 . In this scale, 1 point indicates "I feel comfortable", 2 points indicates "I feel mildly nervous", 3 points indicates "I feel anxious", 4 points indicates "I feel worried and distressed", and 5 points indicates "I feel very scared, I sense changes in my body such as sweating". The validity and reliability study of the scale for the Turkish was performed by llguy et al. (12), and the cut-off point for determining the anxiety level was recommended as 19 . The Cronbach alpha value of the scale was determined as 0.96 (12). The OHIP-14 scale, developed by Slade and Spencer in 1994, consists of 49 questions in 7 domains, which are functional limitation, physical pain, psychological discomfort, physical disability, psychological disability, social disability, and handicaps. The original scale consisting of 49 questions was cut back to 14 questions by Slade. This new scale comprises 2 questions for each of the seven domains. In grading the scale items, 0 points indicates "never", 1 point indicates "rarely", 2 points indicate "sometimes", 3 points indicate "frequently", and 4 points indicate "always". The score is calculated by the sum of these points. The minimum and maximum scores of the scale are 0 and 56 . All of the questions of the scale are in negative form; therefore, a score of 0 states that the OHRQoL is very good, while a score of 56 states that the OHRQoL is very poor. For comparison purposes between domains, the mean score of each domain is obtained by the division of sub-domain scores by the number of questions in that sub-domain. The Turkish validation of the scale was performed by Mumcu et al. (13), and the Cronbach alpha value of the scale was determined as 0.94. McGrath and Bedi (6) developed OHRQoL-UK Scale that consists of 16 questions for 4 domains: two questions for symptoms, 5 questions for physical status, 5 questions for psychological status, and 4 questions for social status. In grading of the scale, 1 point indicates "affects very negatively", 2 points indicate "affects negatively", 3 points indicate "no effect", 4 points indicate "affects positively", and 5 points indicate "affects very positively" (6). The score of the scale is obtained by the sum of these points. The minimum and maximum points of the scale are 5 and 80 . A score of 5 represents very poor OHRQoL, while a score of 80 represents very good OHRQoL. For comparison purposes between domains, the mean score of each domain is obtained by the division of sub-domain scores by the number of questions in that sub-domain. The Turkish validation of the scale was performed by Mumcu et al. (13), and the Cronbach alpha value of the scale was determined as 0.96 . Individuals were examined during daylight with the help of a dental mirror by the same pediatric dentist (S.K.) while sitting in a chair in their own classrooms. Their teeth were not brushed before the examination. Teeth were cleaned with cotton pellets in case of presence of plaque, which make examination difficult. According to the Oral Health Program of the World Health Organization (WHO), decayed, missing, filled teeth (DMFT) index was used to evaluate oral health of the participants (14). Clinical oral hygiene status was assessed by same examiner (S.K.) in accordance with the Community Periodontal Index (CPI) (15), and malocclusion was categorized according to the Dental Aesthetic Index (DAI) (16). Traumatic dental injuries were recorded as absent or present according to Andreasen et al. (17) classification. The structured questionnaire forms and scales were applied to the participants face-to-face by supporting researchers. The data obtained from the examinations were recorded by the pediatric dentist during the examination. The application of the questionnaires and recording of data took about 45-60 minutes for each individual.

\section{Statistical Analysis}

SPSS software version 18.0 was used for statistical analysis. The variables were investigated to determine whether they are normally distributed with the Kolmogorov-Smirnov test. Descriptive analyses are presented using mean \pm standard deviation (minimum-maximum values) for normally distributed variables, whereas median are given for the nonnormally distributed data. Student's t-test was used to 
compare normal continuous variables in independent groups, while Mann-Whitney $U$ tests were used for non-normally distributed data. Chi-square tests were used for the comparison of categorical variables. The Pearson coefficient was used to detect correlations between OHRQoL scores and selected variables (such as dental anxiety levels and DMFT indices). A 5\% type 1 error level was used to infer statistical significance.

\section{Results}

A total of 86 students with mild intellectual disability were enrolled in the study. The mean age of the students was $17.12 \pm 1.40(15-22)$ years. Of these, $68.6 \%$ were male, $31.4 \%$ were female. Of the students, $70.3 \%$ had mothers with an educational level of primary school or less, $65.8 \%$ had fathers with an educational level of primary school or less, the mothers of $17.9 \%$ were working in paid jobs, the fathers of $95.1 \%$ were working in paid jobs, the income levels of $28.9 \%$ were lower than the expense levels the income levels of $71.1 \%$ were equal to or more than the expense levels, and $20.3 \%$ had no health insurance.

The mean DMFT index score of students was 3.10 \pm 2.76 (minimum: 0 - maximum: 11.0). The mean numbers of decayed, filled and missing teeth were 2.32 \pm 2.31 (minimum: 0 - maximum: 10.0), $0.45 \pm 1.32$ (minimum: 0 - maximum: 9 ) and $0.36 \pm 0.74$ (minimum: 0 - maximum: 3), respectively. Of these, 93 $\%$ of the participants did not have a healthy gingival/ periodontal condition. Almost half of the students $(50.0 \%)$ had a definite $(n=21,24.4 \%)$, severe $(n=13$, $15.1 \%)$, or handicapping ( $n=9,10.5 \%)$ malocclusion, and $10 \%$ of the participants stated that they had experienced any dental trauma in the past. Oral examination findings of the participants are given in Table 1. Of the students, $26.5 \%$ stated that they had never been to the dentist, and $57.8 \%$ stated that they had gone to the dentist only when there was a problem. $13.2 \%$ stated that they were going to the dentist once a year or more frequently, and $2.5 \%$ stated that they were going to the dentist less frequently than once a year. Of the students, $20.2 \%$ stated that they never brush their teeth, $50.0 \%$ stated that they sometimes brush their teeth, and $29.8 \%$ stated that they brush their teeth at least once a day.

The mean OHIP-14 score of the children was 25.83 \pm 7.36 (minimum: 14 - maximum: 47). The mean scores obtained by the division of the scores of each sub-domain by the number of questions are as follows: $1.55 \pm 0.80$ for functional limitations; $1.48 \pm 0.69$ for physical pain; $2.53 \pm 0.97$ for psychological discomfort; $2.37 \pm 1.12$ for physical disability; $1.82 \pm 0.96$ for psychological disability; $1.49 \pm 076$ for social disability, and $1.66 \pm 0.91$ for handicap.

The sub-domains of OHIP-14 were determined to be unrelated with gender, the educational level of the parents, the work statuses of the parents, income levels, the social security conditions of the family, the existence of dental trauma, periodontal conditions, and dental anxiety ( $p>0.05)$. Significant relationships were found between the following: brushing frequency and psychological and physical disability sub-domains; the frequency of visits to the dentist and psychological disability sub-domain; malocclusions and social disability sub-domain $(p<0.05)$. Table 2

Table 1. Oral examination findings of the participants

\begin{tabular}{|c|c|c|}
\hline & $n$ & $\%$ \\
\hline \multicolumn{3}{|l|}{ DMFT } \\
\hline$=0$ & 15 & 17.4 \\
\hline$>0$ & 71 & 82.6 \\
\hline \multicolumn{3}{|l|}{ Decayed teeth } \\
\hline$=0$ & 23 & 27.4 \\
\hline$>0$ & 61 & 72.6 \\
\hline \multicolumn{3}{|l|}{ Missing teeth } \\
\hline$=0$ & 64 & 76.2 \\
\hline$>0$ & 20 & 23.8 \\
\hline \multicolumn{3}{|l|}{ Filled teeth } \\
\hline$=0$ & 69 & 82.1 \\
\hline$>0$ & 15 & 17.9 \\
\hline \multicolumn{3}{|l|}{ Malocclusion } \\
\hline Present & 43 & 50.0 \\
\hline Absent & 43 & 50.0 \\
\hline \multicolumn{3}{|c|}{ Periodontal condition } \\
\hline Healthy & 6 & 7.0 \\
\hline Bleeding & 45 & 52.3 \\
\hline Calculus & 28 & 32.6 \\
\hline Pockets $\geq 4 \mathrm{~mm}$ & 7 & 8.1 \\
\hline \multicolumn{3}{|l|}{ Dental trauma } \\
\hline Present & 10 & 11.6 \\
\hline Absent & 76 & 88.4 \\
\hline DMFT: Decayed, $\mathrm{m}$ & & \\
\hline
\end{tabular}


shows relationships between the oral health findings and oral health attitudes of the participants and the sub-domains of OHRQoL-UK Scale. Table 3 shows the relationships between the oral health findings and oral health attitudes of the participants and the subdomains of the (OHIP-14) scale.

The mean OHRQoL-UK score of the students was 50.93 \pm 9.80 (minimum: 34 - maximum: 80 ). The mean scores obtained by the division of the scores of each sub-domain by the number of questions are as follows: $2.97 \pm 0.77$ for symptom sub-domain; $3.17 \pm 0.67$ for physical status; $3.23 \pm 0.67$ for psychological status; and $3.19 \pm 0.63$ for social status.
No significant relationships were found between the sub-domains of OHRQoL-UK and gender, the educational level of the parents, the work stat uses of the parents, income levels, the health insurance status of the family, oral health attitudes of participants (such as the habit of brushing teeth and the frequency of visits to the dentist), malocclusions and periodontal conditions $(p>0.05)$. Significant relationships were found between dental anxiety and the social status sub-domain of OHRQoL-UK, and dental trauma and the psychological and social status sub-domains of OHRQoL-UK $(p<0.05)$. Upon

Table 2. Relationships between the oral health findings and oral health attitudes of the participants and the subdomains of oral health related quality of life-United Kingdom Scale

\begin{tabular}{|c|c|c|c|c|}
\hline & Symptom & Social status & Physical status & Psychological status \\
\hline & Mean \pm SD & Mean \pm SD & Mean \pm SD & Mean \pm SD \\
\hline \multicolumn{5}{|l|}{ Dental trauma } \\
\hline Present & $2.42 \pm 0.44$ & $2.53 \pm 0.46$ & $2.91 \pm 0.71$ & $2.93 \pm 0.20$ \\
\hline Absent & $3.03 \pm 0.79$ & $3.26 \pm 0.62$ & $3.19 \pm 0.67$ & $3.25 \pm 0.70$ \\
\hline $\mathrm{t}$ & -1.976 & -3.011 & -1.052 & -2.784 \\
\hline $\mathrm{p}$ & 0.052 & 0.003* & $0.296 *$ & 0.013* \\
\hline \multicolumn{5}{|l|}{ Malocclusion } \\
\hline Present & $3.01 \pm 0.82$ & $3.14 \pm 0.63$ & $3.05 \pm 0.71$ & $3.17 \pm 0.67$ \\
\hline Absent & $2.95 \pm 0.75$ & $3.24 \pm 0.64$ & $3.30 \pm 0.61$ & $3.30 \pm 0.64$ \\
\hline $\mathrm{t}$ & 0.345 & -0.671 & -1.668 & -0.874 \\
\hline$p$ & 0.731 & 0.504 & 0.099 & 0.385 \\
\hline \multicolumn{5}{|l|}{ Dental anxiety } \\
\hline Present & $2.70 \pm 0.72$ & $2.96 \pm 0.49$ & $3.00 \pm 0.62$ & $3.01 \pm 0.63$ \\
\hline Absent & $3.06 \pm 0.78$ & $3.28 \pm 0.66$ & $3.24 \pm 0.69$ & $3.30 \pm 0.67$ \\
\hline $\mathrm{t}$ & 1.945 & 2.360 & 1.423 & 1.796 \\
\hline$p$ & 0.055 & $0.022 *$ & 0.158 & 0.076 \\
\hline \multicolumn{5}{|l|}{ Visiting dentist } \\
\hline Never/problem based & $3.00 \pm 0.87$ & $3.29 \pm 0.66$ & $3.28 \pm 0.73$ & $3.29 \pm 0.69$ \\
\hline Other & $2.93 \pm 0.60$ & $3.04 \pm 0.56$ & $3.01 \pm 0.54$ & $3.12 \pm 0.63$ \\
\hline $\mathrm{t}$ & 0.353 & 1.778 & 1.930 & 1.115 \\
\hline $\mathrm{p}$ & 0.725 & 0.079 & 0.057 & 0.268 \\
\hline \multicolumn{5}{|l|}{ Tooth brushing } \\
\hline Never & $2.982 .98 \pm 0.71$ & $3.13 \pm 0.60$ & $3.13 \pm 0.66$ & $3.16 \pm 0.60$ \\
\hline Other & $3.04 \pm 0.85$ & $3.35 \pm 0.69$ & $3.30 \pm 0.69$ & $3.40 \pm 0.78$ \\
\hline $\mathrm{t}$ & -0.317 & -1.427 & -1.071 & -1.379 \\
\hline$p$ & 0.752 & 0.157 & 0.288 & 0.176 \\
\hline \multicolumn{5}{|l|}{${ }^{*} p<0.05$} \\
\hline
\end{tabular}


examination of the relationship between dental anxiety scores and the sub-domains of OHRQoLUK, a negative, moderately significant relationship was found in the symptoms sub-domain $(r=-0.320$, $p=0.003) ;$ a negative, mildly significant relationship was found in the psychological status sub-domain $(r=-0.227, p=0.040)$; and a negative, moderately significant relationship was found in the social status sub-domain ( $r=-0.269, p=0.014)$. The examination of the relationship between anxiety scores and the subdomains of OHIP-14 revealed that there were no significant relationships except for the handicap sub- domain ( $p>0.05$ ). A negative, moderately significant relationship was found between dental anxiety score and the handicap sub-domain ( $r=-0.276, p=0.011$ ). No significant relationships were found between the DMFT scores of the students and the sub-domains of both quality of life scales ( $p>0.05$ ). Table 4 shows the relationships between the OHRQoL scales (OHIP-14, OHRQoL-UK) and dental anxiety and DMFT.

The mean MDAS score of the students was 13.29 \pm 6.58 . $28.0 \%(n=24)$ of the students were determined to have dental anxiety. No significant relationships were found between dental anxiety and

Table 3. Relationships between the oral health findings and oral health attidudes of the participants and the subdomains of the Oral Health Impact Profile-14 scale

\begin{tabular}{|c|c|c|c|c|c|c|c|}
\hline & $\begin{array}{l}\text { Functional } \\
\text { limitation }\end{array}$ & Physical pain & $\begin{array}{l}\text { Psychological } \\
\text { discomfort }\end{array}$ & $\begin{array}{l}\text { Physical } \\
\text { disability }\end{array}$ & $\begin{array}{l}\text { Psychological } \\
\text { disability }\end{array}$ & $\begin{array}{l}\text { Social } \\
\text { disability }\end{array}$ & Handicap \\
\hline & Mean \pm SD & Mean \pm SD & Mean \pm SD & Mean \pm SD & Mean \pm SD & Mean \pm SD & Mean \pm SD \\
\hline \multicolumn{8}{|c|}{ Dental trauma } \\
\hline Present & $1.35 \pm 0.47$ & $1.42 \pm 0.53$ & $2.58 \pm 1.02$ & $2.21 \pm 0.90$ & $2.14 \pm 1.40$ & $1.50 \pm 0.50$ & $1.57 \pm 0.60$ \\
\hline Absent & $1.58 \pm 0.83$ & $1.50 \pm 0.71$ & $2.56 \pm 0.96$ & $2.43 \pm 1.13$ & $1.80 \pm 0.92$ & $1.51 \pm 0.79$ & $1.69 \pm 0.95$ \\
\hline $\mathrm{t}$ & -0.708 & -0.257 & 0.043 & -0.496 & 0.887 & -0.044 & -0.325 \\
\hline$p$ & 0.481 & 0.798 & 0.966 & 0.621 & 0.378 & 0.965 & 0.746 \\
\hline \multicolumn{8}{|c|}{ Malocclusion } \\
\hline Present & $1.57 \pm 0.71$ & $1.53 \pm 0.68$ & $2.52 \pm 0.90$ & $2.46 \pm 1.19$ & $1.92 \pm 0.91$ & $1.68 \pm 0.89$ & $1.80 \pm 0.98$ \\
\hline Absent & $1.52 \pm 0.90$ & $1.38 \pm 0.68$ & $2.48 \pm 1.07$ & $2.24 \pm 1.09$ & $1.70 \pm 1.03$ & $1.34 \pm 0.59$ & $1.54 \pm 0.86$ \\
\hline $\mathrm{t}$ & 0.305 & 1.021 & 0.172 & 0.851 & 0.974 & 2.006 & 1.247 \\
\hline$p$ & 0.761 & 0.311 & 0.864 & 0.397 & 0.333 & $0.048 *$ & 0.216 \\
\hline \multicolumn{8}{|c|}{ Dental anxiety } \\
\hline Present & $1.47 \pm 0.68$ & $1.58 \pm 0.63$ & $2.62 \pm 1.03$ & $2.45 \pm 1.15$ & $1.85 \pm 0.99$ & $1.54 \pm 0.75$ & $1.43 \pm 0.71$ \\
\hline Absent & $1.56 \pm 0.84$ & $1.45 \pm 0.72$ & $2.49 \pm 0.94$ & $2.34 \pm 1.11$ & $1.83 \pm 0.97$ & $1.47 \pm 0.77$ & $1.76 \pm 0.98$ \\
\hline $\mathrm{t}$ & 0.453 & -0.737 & -0.568 & -0.430 & -0.088 & -0.359 & 1.487 \\
\hline$p$ & 0.652 & 0.463 & 0.572 & 0.669 & 0.930 & 0.720 & 0.141 \\
\hline \multicolumn{8}{|c|}{ Visiting dentist } \\
\hline Never & $1.47 \pm 0.70$ & $1.50 \pm 0.67$ & $2.36 \pm 0.98$ & $2.47 \pm 1.15$ & $1.80 \pm 1.03$ & $1.53 \pm 0.77$ & $1.60 \pm 0.91$ \\
\hline Other & $1.69 \pm 0.94$ & $1.48 \pm 0.74$ & $2.84 \pm 0.89$ & $2.25 \pm 1.06$ & $1.87 \pm 0.87$ & $1.43 \pm 0.75$ & $1.78 \pm 0.92$ \\
\hline $\mathrm{t}$ & -1.262 & 0.097 & -2.237 & 0.856 & -0.327 & 0.582 & -0.890 \\
\hline$p$ & 0.211 & 0.923 & $0.028^{*}$ & 0.394 & 0.744 & 0.562 & 0.376 \\
\hline \multicolumn{8}{|c|}{ Tooth brushing } \\
\hline Never & $1.59 \pm 0.82$ & $1.51 \pm 0.72$ & $2.54 \pm 0.97$ & $2.18 \pm 1.12$ & $1.99 \pm 1.00$ & $1.53 \pm 0.81$ & $1.64 \pm 0.79$ \\
\hline Other & $1.44 \pm 0.79$ & $1.42 \pm 0.64$ & $2.46 \pm 0.99$ & $2.74 \pm 1.03$ & $1.36 \pm 0.51$ & $1.36 \pm 0.58$ & $1.78 \pm 1.17$ \\
\hline $\mathrm{t}$ & 0.788 & 0.579 & 0.353 & -2.149 & 3.801 & 1.102 & -0.616 \\
\hline$p$ & 0.433 & 0.564 & 0.725 & $0.035^{*}$ & $0.000^{*}$ & 0.275 & 0.539 \\
\hline \multicolumn{8}{|l|}{$\begin{array}{l}{ }^{*} p<0.05 \\
\text { SD: Stanc }\end{array}$} \\
\hline
\end{tabular}




\begin{tabular}{|c|c|c|c|c|}
\hline \multirow{2}{*}{$\begin{array}{l}\text { Table 4. Relationships } \\
\text { quality of life scales } \\
\text { oral health related qua } \\
\text { dental anxiety and dec }\end{array}$} & \multicolumn{2}{|c|}{ Dental anxiety } & \multicolumn{2}{|l|}{ DMFT } \\
\hline & $r$ & $\mathbf{p}$ & $\mathbf{r}$ & $\mathbf{p}$ \\
\hline \multicolumn{5}{|l|}{ OHIP-14 } \\
\hline Functional limitation & -0.101 & 0.360 & 0.005 & 0.960 \\
\hline Physical pain & 0.041 & 0.712 & 0.194 & 0.074 \\
\hline Psychological discomfort & 0.204 & 0.064 & 0.029 & 0.791 \\
\hline Physical disability & -0.040 & 0.719 & 0.112 & 0.303 \\
\hline Social disability & -0.020 & 0.857 & -0.112 & 0.307 \\
\hline Psychological disability & 0.085 & 0.440 & 0.040 & 0.716 \\
\hline Handicap & -0.276 & $0.011 *$ & -0.088 & 0.419 \\
\hline \multicolumn{5}{|l|}{ OHRQoL } \\
\hline Symptom & -0.320 & $0.003 *$ & 0.007 & 0.950 \\
\hline Physical status & -0.159 & 0.151 & -0.003 & 0.976 \\
\hline Psychological status & -0.227 & $0.040 *$ & 0.072 & 0.518 \\
\hline Social status & -0.269 & $0.014^{*}$ & 0.077 & 0.482 \\
\hline $\begin{array}{l}{ }^{*} p<0.05 \\
\text { DMFT: Decayed, missing, } \\
\text { Profile-14, OHRQoL: Oral }\end{array}$ & Era & & al $\mathrm{H}$ & \\
\hline
\end{tabular}

the educational levels of parents, the work statuses of parents, the economic status of the family, and health insurance status ( $p>0.05$ ); however, the rate of students with dental anxiety was found to be higher among the female students as compared to the male students (48.1\% vs $19.3 \%)\left(x^{2}=7.472, p=0.006\right)$. In addition, the median DMFT scores of students with and without dental anxiety were determined as 1 (minimum: 0, maximum: 10) and 3 (minimum:0, maximum: 11$)$ respectively $(U=385.5 ; p=0.001)$. The median number of decayed teeth in students with and without dental anxiety were found to be 1 (minimum: 0 , maximum: 9) and 2 (minimum: 0 , maximum: $10)$, respectively $(U=436.6 ; p=0.017)$. There was no significant difference in terms of filled or missing teeth $(p>0.05)$.

\section{Discussion}

IIn this study, we determined that dental trauma and malocclusions negatively affect the social and psychological sub-domains of the OHRQoL scales. Dental anxiety was also determined to be related to the social, psychological and handicap sub-domains of the quality of life scales. According to the data of the present study, the rate of dental anxiety among mildly intellectually disabled individuals is substantial $(28.0 \%)$, and it affects their OHRQoL. Also, similar to the healthy individuals, the existence of malocclusion and dental traumas that lead aesthetic disorders affect OHRQoL (18-21).

Mildly intellectually disabled people learn language with some delay, but most achieve the ability to use speech, to hold conversations, and to engage in the clinical interview. Most of them also achieve full independence in self-care (eating, washing, dressing, bowel and bladder control) and in practical and domestic skills, even if the rate of development is considerably slower than normal (22). The higher life skills of the mildly intellectually disabled individuals as compared to those with more severe disabilities allow them to be educable in oral hygiene, one of the self-care practices. However, the subject of oral health is still neglected in this group of individuals. Due to their cooperation problems, intellectually disabled individuals make up the group that benefits least from oral and dental healthcare services (23). Today, the increased awareness of their families, increased education of the dentists regarding this subject, the changing viewpoint towards disabled individuals, and the administration of advanced treatment methods such as general anesthesia and conscious sedation in many centers have rendered the treatments of intellectually disabled individuals possible. However, the conducted studies still show that the incidence of decayed teeth is higher among the disabled individuals as compared to healthy individuals $(24,25)$. In many studies examining the oral health of intellectually disabled individuals, their oral health was determined to be worse than the healthy individuals. The mean DMFT scores were as follows in studies of Shaw et al.

(26), Gizani et al. (27), and Jain et al. (28) respectively: $1.85 ; 2.90 ; 2.60$. In a Turkish study that was performed on a similar disabled population, this value was found to be 3.75 (23). In our study, the mean DMFT score of individuals was 3.10, and 93\% of all participants had unhealthy periodontal tissue. This study shows that our study group received less dental treatment, and they need special care and periodic dental examinations. The high DMFT score and poor periodontal health in our study group may be explained by less frequent visits to the dentist and irregular tooth brushing habits. $26.5 \%$ of the 
participants in this study stated that they had never been to the dentist, and $20.2 \%$ reported never having brushed their teeth. In the present study, teethbrushing frequency was found to be related to the psychological discomfort and physical disability subdomains of OHIP-14, while the frequency of dentist visits was found to be related to the psychological discomfort sub-domain of OHIP-14.

In our study, $28.0 \%$ of the participants were found to exhibit dental anxiety. The dental anxiety level was found to be higher among females than males, which is in accordance with the other studies conducted on healthy individuals in the literature $(29,30)$. The mean DMFT score was higher among individuals with dental anxiety than those without dental anxiety. Researchers concur that individuals with higher dental anxiety levels may have traumatic dental treatment histories. Ilguy et al. (12) applied MDAS to a group of Turkish patients and they reported the dental anxiety level as $8.8 \%$. In their study conducted on 1148 individuals, Appukuttan et al. (31) determined that the dental anxiety level was $3 \%$, and this value was lower in their country than in industrial countries such as England, Turkey and South Ireland. This low rate may be due to the fact that their study group was comprised of normal individuals with no limitations. The higher rate of dental anxiety found in our study may be due to the fact that mildly intellectually disabled individuals inadequately benefit from oral healthcare services; their oral health is neglected, and they have insufficient information regarding dental treatment methods. The number of studies evaluates the dental anxiety levels among intellectually disabled individuals is scarce. Martin et al. (32) determined the rate of dental anxiety was $40 \%$ in their study conducted on 132 patients that require special care and 72 caregivers. Since it was conducted on patients who require special care, the high anxiety rate may be expected (32).

Although OHRQoL has been evaluated in many different populations and healthy individuals using different parameters, the number of studies conducted on intellectually disabled individuals is very limited. Chang et al. (8) study conducted on 102 individuals determined that the OHRQoL improved after dental treatments performed under general anesthesia. This finding shows that this option should not be disregarded in dental treatment planning. Loureiro et al. (33) applied the OHIP-14 scale to the mothers of individuals between the ages of 6 and 20 who have Down syndrome and showed that the periodontal problems of the children had a negative effect on the OHRQoL. There are studies that evaluate the effects of parameters such as malocclusion and dental trauma on the OHRQoL in healthy individuals, but no studies have been conducted on mildly intellectually disabled individuals. In our study, we determined that the existence of dental trauma and malocclusion negatively affected the OHRQoL of mildly intellectually disabled individuals. Therefore, depending on the level of patient cooperation orthodontic treatments and treatments of teeth affected by dental traumas in mildly intellectually disabled individuals should not be neglected. Because OHIP-14 scale focuses only on the negative effects of OHRQoL, we used OHIP-14 and OHRQoL-UK scales together to evaluate the OHRQoL. In our study, we detected a significant relationship between dental trauma and the psychological status and social status sub-domains of OHRQoL, and between malocclusion and social disability subdomain of OHIP-14. Since both scales are able to detect the relationships between different variables under the same domain, we believe that the usage of OHIP-14 and OHRQoL-UK scales together will prove beneficial. A negative moderately significant relationship was found between dental anxiety and the symptom, psychological status, and social status sub-domains of OHRQoL-UK in our study. This finding is in accordance with the results of McGrath and Bedi's (6) study conducted on 1800 participants (6). A negative moderately significant relationship was found between the handicap sub-domain of OHIP-14 scale and dental anxiety. Differing from other studies examining OHRQoL, in this study, the effects of dental trauma, malocclusion, and dental anxiety on the OHRQoL were evaluated in detail. The results of this study are important in terms of demonstrating the dental anxiety and OHRQoL data of a rarely studied, neglected population.

\section{Study Limitations}

The study was not free of limitations. First limitation is the cross-sectional design of the study. Longitudinal studies are needed to fully understand the association of oral health and dental anxiety on OHRQoL of individuals with mild intellectual disability. Second, the oral examinations were performed in the 
participants' school and radiographic examination could not be performed.

\section{Conclusion}

In order to increase the quality of life of the working group due to oral health, it is necessary to improve the oral and dental health of this neglected population. For this reason, this special group must be able to adequately benefit from dental healthcare services whenever needed. In these schools for disabled individuals, it will be beneficial to structure the dental healthcare services to provide continuous service within the scope of school health programs. We also believe that increasing the periodic examination frequency in these groups with special needs will prove highly valuable. Due to the high anxiety levels among this group, advanced behavior control techniques such as general anesthesia and sedation may be used to prevent further development of dental anxiety.

\section{Ethics}

Ethics Committee Approval: The approval for this cross-sectional study was obtained from the Ethics Committee for Non-Interventional Studies, Adnan Menderes University, Faculty of Medicine (2016/765).

Informed Consent: The written informed consent was obtained from the students and their caregivers.

Peer-review: Externally and internally peerreviewed.

\section{Authorship Contributions}

Surgical and Medical Practices: S.K., F.A., F.A., D.Y., P.O., Concept: S.K., Design: S.K., Data Collection or Processing: S.K., F.A., F.A., D.Y., P.O., Analysis or Interpretation: F.A., Literature Search: S.K., Writing: S.K.

Conflict of Interest: No conflict of interest was declared by the authors.

Financial Disclosure: The authors declared that this study received no financial support.

\section{References}

1. Altun C, Guven G, Akgun OM, Akkurt MD, Basak F, Akbulut E. Oral health status of disabled individuals attending special schools. Eur J Dent 2010; 4: 361-6.

2. Hennequin M, Faulks D, Roux D. Accuracy of estimation of dental treatment need in special care patients. J Dent 2000; 28: 131-6.
3. Glassman P, Miller CE, Lechowick L. A dental school's role in developing a rural, community-based, dental care delivery system for individuals with developmental disabilities. Spec Care Dentist 1996; 16: 188-93.

4. Beange HP. Caring for vulnerable population: Who will take responsibility for those getting a raw deal from the health care system?. Med J Aust 1996; 164: 159-60.

5. Gordon SM, Dionne RA, Snyder J. Dental fear and anxiety as a barrier to accessing oral health care among patients with special health care needs. Spec Care Dent 1998; 18: 88-92.

6. McGrath C, Bedi R. Population based norming of the UK oral health related quality of life measure (OHRQoL-UKC). Br Dent J 2002; 193: 521-4.

7. Locker D, Matear D, Stephens M, Jokovic A. Oral health-related quality of life of a population of medically compromised elderly people. Community Dent Health 2002; 19: 90-7.

8. Chang J, Patton LL, Kim HY. Impact of dental treatment under general anesthesia on the oral health-related quality of life od adolescents and adults with special needs. Eur J Oral Sci 2014; 122: 363-71.

9. Humpris GM, Morrison T, Lindsay S. The Modified Dental Anxiety Scale: validation and United Kingdom norms. Community Dent Health 1995; 12: 143-50.

10. Owens PL, Kerker BD, Zigler E, Horwitz SM. Vision and oral health needs of individuals with intellectual disability. Ment Retard Dev D R 2006; 12: 28-40.

11. Morgan JP, Minihan PM, Starck PC, Finkelman MD, Yantsides $\mathrm{KE}$, Park A, et al. The oral health status of 4732 adults with intellectual and developmental disabilities. J Am Dent Assoc 2012; 143: 838-46.

12. Ilguy D, Ilguy M, Dincer S, Bayırlı G. Reliability and validity of the Modified Dental Anxiety Scale in Turkish patients. J Int Med Res 2005; 33: 252-9.

13. Mumcu G, Inanc N, Ergun T, Ikiz K, Gunes M, Islek U, et al. Oral health related quality of life is affected by disease activity in Behcet's disease. Oral Dis 2006; 12: 145-51.

14. WHO World Health Organization. Oral Health Surveys, Basic Methods, 4th edition. Geneva: World Health Organization, 1997.

15. Ainamo J, Barnes D, Beagrie G, Cutress T, Martin J, SardoInfirri J. Development of the World Health Organization (WHO) community periodontal index of treatment needs (CPITN). Int Dent J 1982; 32: 281-91.

16. Jenny J, Cons NC. Comparing and contrasting two orthodontic indices, the Index of Orthodontic Treatment Need and the Dental Aesthetic Index. Am J Orthod Dentofacial Orthop 1996; 110: 410-6.

17. Andreasen JO, Andreasen FM, Anderson L. Textbook and color atlas of traumatic injuries to the teeth, 4th edition. Copenhagen:Munksgaard;2007.

18. IIma SCM, Marcanes W, Sheiam A. Impact of traumatic injuries to the permanent teeth on the oral health-related quality of life in 12-14 year-old children. Community Dent Oral Epidemiol 2002; 30: 193-8. 
19. Oliveira C, Sheiham A. Orthodontic treatment and its impact on oral health-related quality of life in Brazilian adolescents. J Orthod 2004; 31: 20-7.

20. Ramos-Jorge ML, Bosco VL, Peres MA, Nunes ACGP. The impact of treatment of dental trauma on the quality of life of adolescentsa case control study in southern Brazil. Dent Traumatol 2007; 23: 114-9.

21. Scapini A, Feldens CA, Ardenghi TM, Kramer PF. Malocclusion impacts adolescents' oral health-related quality of life. Angle Orthod 2012; 83: 512-8.

22. Luckasson R, Borthwick-Duffy S, Buntinx WH, Coulter DL, Craig EMP, Reeve A, et al. Mental retardation: Definition, classification and systems of supports. Workbook mental retardation 2002.

23. Cokpekin F, Koymen G, Basak F, Akbulut E, Altun C. The evaluation of oral health of children attending the school of handicapped children. Gulhane Med J 2003; 45: 228-32.

24. Anders PL, Davis EL. Oral health of patients with intellectual disabilities: a systemic review. Spec Care Dentist 2010; 30: 110-7.

25. Turner S, Sweeney M, Kennedy C, Macpherson L. The oral health of people with intellectual disability participating in the UK Special Olympics. J Intellect Dev Disabil Res 2008; 52: 29-36.

26. Shaw L, Maclaurin ET, Foster TD. Dental study of handicapped children attending special schools in Birmingham, UK. Community Dent Oral Epidemiol 1986; 14: 24-7.
27. Gizani S, Declerck D, Vinckier F, Martens L, Marks L, Coffin G. Oral health condition of 12 year old handicapped children in Flanders (Belgium). Community Dent Oral Epidemiol 1997; 25: 352-7.

28. Jain M, Mathur A, Sawla L, Choudhary G, Kabra K, Duraiswamy P, et al. Oral health status of mentally disabled subjects in India. J Oral Sci 2009; 51: 333-40.

29. Hakeberg M, Berggren U, Carlsson SG. Prevalance of dental anxiety in an adult population in amajor urban area in Sweden. Community Dent Oral Epidemiol 1992; 20: 97-101.

30. Neverlien PO. Normative data for Corah's Dental Anxiety Scale (DAS) for the Norwegian adult population. Community Dent Oral Epidemiol 1990; 18: 162.

31. Appukuttan D, Subramanian S, Tadepalli A, Damodaran LK. Dental anxiety among adults: an epidemiological study in South India. North Am j Med Sci 2015; 7: 13-8.

32. Martin MD, Kinoshita-Byrne J, Getz T. Dental fear in special needs clinic population of persons with disabilities. Spec Care Dentist 2002; 22: 99-102.

33. Loureiro A, Costa F, Costa J. The Impact of periodontal disease on the quality of life of individuals with Down syndrome. Down Syndr Res Prac 2007; 12: 50-4. 